\title{
A LONGA JORNADA
}

\section{Prof. Ruy Cirne Lima}

Trilhamos, durante decênios, lado a lado, caminhos paralelos. O curso secundário, primeiro; depois, o curso jurídico, e, enfim, a carreira do magistério jurídico. Era Elpídio Paes, baixo de estatura, cabelo ralo a dilatar-lhe sonhadoramente a fronte, homem, porém, de perfil forte, olhar firme e gestos secos.

O traço mais vivo de sua feição exterior era a exatidão, exatidão no vestir-se, no andar e no conduzir-se. O livro, sempre outro, de que não se apartava nunca, sobraçava-o com rigor reverencial, jamais se permitindo o trazê-lo, a balouçar-se preguiçosamente, à ponta dos dedos.

Voltado, desde a adolescência, para o estudo das letras clássicas, sua inclinação, nos lindes da Ciência Jurídica, haveria de definir-se, como se definiu, para o Direito Romano. Fora a disciplina, suprimida, do currículo das Faculdades de Direito, pela reforma do ensino de 1931. Nem mesmo, entretanto, as reformas de ensino do Brasil podem dizer-se mais resistentes que o Direito Romano. Reinstalado, no currículo jurídico, o Direito Romano, Elpídio Paes prestou concurso, do qual se saiu brilhantemente, e entrou a ensinar as instituições jurídicas de Roma aos nossos estudantes.

Suas relações fundiam, de modo admirável, a estrutura jurídica permanente e a fluxo transformador da história. Nelas, como em sua mesma dissertação de concurso, a exatidão, que the era como uma segunda natureza, imprimia contornos precisos a cada conceito e ao conjunto, aquela harmonia, que só da nitidez perfeita realmente surge e se irradia.

A sua vez, a exposição jurídica particularmente, a do Direito Romano, revela, desde logo, algo de surpreendente para o estudante: mais o direito modifica os fatos, que os fatos modificam o direito. A codificação romana do século VI, ajustaram-se, lenta e progressivamente, todas as legislações contemporâneas, já não anteriormente modeladas pelo Direito Romano, como o sistema jurídico anglo-america- 
no, cujas linhas capitais diferem das dos sistemas jurídicos do continente europeu, somente por dimanarem, imediatamente, do Direito Romano clássico, já muito antes implantado, pela conquista; nas ilhas britânicas.

Essa perturbadora surprêsa ganhava-lhe, sem detenca, o interesse dos estudantes. Exerceu, assim, Elpídio Paes, influência decisiva sobre a formação jurídica de nossa mocidade. Não só lhe descerrava ao início do curso, a larga visão de uma organização jurídica, que o tempo faz, cada dia mais atual e nova, senão, também, lhes incutia pacientemente a exatidão, a fidelidade ao pormenor, como diretiva básica do aprender.

Nenhum de seus estudantes, estejamos seguros, o es quecerá, nem ao professor excepcional, nem ao homem compreensivo e afetuoso, que lhes resolvia as dúvidas, incansavelmente os guiava por entre as dificuldades do estudo e generosamente, lhes aplacava os ressentimentos e as queixas.

Agora, para Elpídio Paes, cessou a longa jornada, nem sempre fácil e agradável. Veio-lhe a morte às vésperas do repouso na aposentadoria, como a substituir-se a esta, recompensa demasiado pequena para esforço tamanho, de tão profunda riqueza interior.

Todos os caminhos desta vida, certo, mais dia menos dia levam-nos ao crespúsculo. Mas, esse crepúsculo que, do lado de cá, nos aparece como crepúsculo da tarde, é, do lado de lá, o crepúsculo da aurora, - dessa alvorada que se abre gloriosamente, por entre as sombras do tempo, para os que, do tempo, corajosa e confiantemente, avançam ao encontro da eternidade.

"Pelo céu da tarde uma primavera se ergue a florescer". Tal, o verso de Hölderlin; tal o misterioso sentido que se há de atribuir à morte, como fim de todas as jornadas.

\section{A DIGNIDADE DO MAGISTERIO}

\section{Prof. Elmo Pilla Ribeiro}

A semelhança de outras instituições de ensino, a Faculdade de Direito da Universidade Federal do Rio Grande do Sul possui sempre uma nobre linhagem de professores, perceptíveis entre os demais, e que nasceu com ela própria, constituindo-se em verdadeiros numes tutelares daquela casa de ensino. Suas figuras e seus exemplos se têm imposto de geração a geração por uma transfusão silenciosa de estilo, de sorte a que, professores, sem o desejarem, fazem discípulos entre seus pares, o que tem permitido sempre a existência de figuras singulares que, diuturnamente, nos dão lições de algo que não consta nos currículos acadêmicos nem é formalmente exigido para o ingresso no magistério superior.

Trata-se de uma bela estirpe de mestres que se notabilizam, não apenas pelo perfeito conhecimento da matéria que ensinam e cabal desempenho de suas atribuições, mas ainda por inconfundível estilo de ser e de viver. Probidade intelectual e moral, verticalidade de conduta, independência de espírito? Desde logo - mas não somente.

Sente-se que os anima uma idéia matriz, que é uma verdadeira constante em suas vidas: e do sentido e relevância da missão que cumprem, dos quais decorre a dignidade desta.

Se desprovidos de recursos materiais, não vêem no magistério apenas uma profissão; se bem sucedidos em outras atividades, não o têm como uma simples complementação de ganhos.

Não buscaram o magistério para auto-satisfação da vaidade, para dele fazer sua tribuna ou transformá-lo em trampolim à conquista de posições, honrarias ou dignidades. São fundamentalmente professores e querem conservar-se tais.

Move-se um vigoroso impulso anímico, uma irrefreável tendência - como a do artista, do escritor, do pastor de almas e a da própria maternidade na mulher - que só se 